\title{
Navike i stavovi o prehrani maturanata Medicinske škole
}

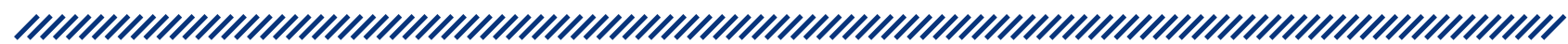

1 Marija Gudeljević

2 Željko Jovanović

1 Klinički bolnički centar Rijeka

2 Sveučilište u Rijeci, Fakultet zdravstvenih studija o štetnosti alkoholnih pića i duhanskih proizvoda. Daljnjom edukacijom i obrazovnim programima o pravilnoj prehrani i njezinim učincima na zdravlje preventivno se djeluje na zdravlje populacije u cjelini.

\section{Sažetak}

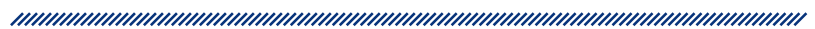

Prehrambene navike imaju važan utjecaj na zdravlje organizma. Pravilnom prehranom, koja obuhvaća uravnoteženu količinu i kvalitetu unesene hrane, konzumiranje svježeg voća i povrća oslobođenog od raznih štetnih utjecaja (zagađenja, pesticida i sl.), ribe, mesa u odgovarajućim količinama, ograničenje količine šećera, soli i masti i dr. može se unaprijediti zdravstveno stanje organizma te smanjiti rizik oboljenja od pojedinih bolesti. Razvijanje svijesti o pravilnoj prehrani kod adolescenata iznimno je važno u prevenciji oboljenja od različitih kroničnih nezaraznih bolesti u kasnijoj dobi. Istraživanje provedeno na uzorku od 74 maturanta Medicinske škole u Rijeci pokazalo je pozitivan stav maturanata povezano sa zdravom prehranom i prihvaćanjem pravilne prehrane kao načina života. ITM ispitanika iznosio je 23 te ukazuje da u prosjeku imaju normalnu tjelesnu težinu. Rezultati ankete pokazali su zadovoljavajuće prehrambene navike maturanata. Nedostaci u prehrani uočeni su u nedostatnom konzumiranju voća i povrća te ribe. Pažnju je potrebno usmjeriti i na promjene prehrambenih navika tijekom boravka u školi, preskakanje obroka i kasne večere te na dodatnu edukaciju srednjoškolaca

Ključne riječi: maturanti, prehrambene navike, pravilna prehrana, prevencija, zdrav

Datum primitka: 16.11.2021.

Datum prihvaćanja: 15.12.2021.

https://doi.org/10.24141/1/8/1/8

Adresa za dopisivanje:

A: Sveučilište u Rijeci, Fakultet zdravstvenih studija, Katedra za temeljne medicinske znanosti,

Viktora Cara Emina 5, Rijeka

E-mail: zeljko.jovanovic@uniri.hr

M: 098329495 


\section{Uvod i cilj istraživanja}

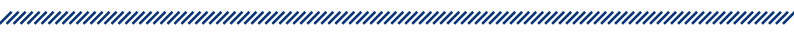

Potreba za hranom jedna je od osnovnih ljudskih potreba. Hranom se zadovoljavaju osnovne tjelesne $i$ fiziološke potrebe čovjeka, ali hrana često predstavlja način i sredstvo kojim se zadovoljavaju najrazličitija emotivna stanja. Ljudi jedu i kada nemaju osjećaj gladi, ispunjavajući pri tome različita emotivna stanja i tako doživljavaju ugodu, veselje ili sreću koju im pruža hrana. Primarni je cilj zadovoljenje osnovnih čovjekovih potreba, no sam proces regulacije hrane vrlo je kompleksan i pod utjecajem brojnih čimbenika, od genetike do okoline i društva. Proces učenja o prehrambenim navikama počinje već prvim mjesecima djetetova života i već u ranoj dobi dojenčeta mogu se stvoriti i pravilni i nepravilni mehanizmi kontrole gladi i sitosti. ${ }^{1,2}$ Put od informacija, preko znanja do navika i vrijednosnih stavova o prehrani jedan je od najvažnijih za kvalitetu zdravlja i života ljudi. Prehrambene se navike tijekom razvoja djeteta, u doba adolescencije i u kasnijem životu mijenjaju pod utjecajem promjena načina života. Međutim, određena usvojena pravila povezana s prehranom ostaju zauvijek. Stoga je važno da djeca već u ranoj dobi usvoje osnovne činjenice i znanja, steknu navike i razviju vrijednosne stavove o pravilnoj prehrani te da mogu donositi samostalno kvalitetnu odluku o načinu hranjenja i odabiru hrane kako bi mogla zadovoljiti svoje osnovne tjelesne i emocionalne potrebe za hranom a da pritom ne narušavaju svoje zdravlje. Ako se usvoje pravilne prehrambene navike, može se učinkovito djelovati u smjeru prevencije niza bolesti, posebice pretilosti te komplikacija pretilosti kao što su kardiovaskularne bolesti i bolesti krvnih žila, dijabetesa tipa 2 i drugih kroničnih nezaraznih i malignih bolesti. ${ }^{1}$ Razdoblje adolescencije i inače je vrlo zahtjevan period za mentalno i sveukupno zdravlje, kao što je i vrlo zahtjevno razvojno razdoblje praćeno visokim nutritivnim rizikom uz povećane energetske potrebe, potrebe za proteinima, kalcijem i željezom..$^{3,4}$ Ako adolescenti svakodnevno ne ostvaruju odgovarajuću prehranu, može doći do smanjenja fizičkih i umnih sposobnosti za obavljanje školskih obveza. Kod starijih adolescenata dolazi do prilagodbe promjenama koje zahtijeva njihov razvoj, pa je u tom razdoblju veoma važno razvijanje prehrambenih navika koje vode sprječavanju bolesti i unaprjeđenju zdravlja. Prehrambene navike znatno utječu na zdravlje ljudi i pravilnom prehranom može se spriječiti razvoj zdravstvenih rizika i unaprijediti zdravlje pa je cilj istraživanja bio analizirati prehrambene navike, znanje i stavove o prehrani maturanata Medicinske škole u Rijeci. Također, s obzirom na utjecaj pandemije bolesti COVID-19 na sve aspekte života, jedan od ciljeva bio je i utvrditi smatraju li maturanti da postoji dodatna interakcija i utjecaj loših navika i pandemije bolesti COVID-19 na prehranu i njihovo zdravlje.

\section{Ispitanici i metode}

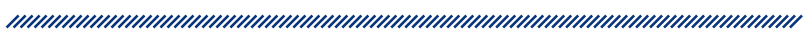

Provedena je presječna studija tijekom svibnja 2021. na prigodnom uzorku 74 maturanta, 67 ženskog i sedam muškog spola iz Medicinske škole u Rijeci u dobi između 18 i 20 godina. Za potrebe istraživanja izrađen je vlastiti upitnik i provedeno anonimno anketiranje uz pomoć online ankete izrađene u programu Google Forms. Anketa je distribuirana učenicima u suradnji sa psihologom Medicinske škole u Rijeci putem programa Microsoft Teams. Provedbu ankete odobrilo je Etičko povjerenstvo Medicinske škole u Rijeci. Anketa je sadržavala 46 pitanja svrstana u četiri skupine. Prva skupina pitanja bila su opća pitanja koja obuhvaćaju sociodemografska obilježja ispitanika, a mjerenje antropometrijskih parametara proveli su maturanti samostalno. Druga skupina pitanja usmjerena je na prehrambene navike ispitanika, dok se treća skupina odnosila na stavove ispitanika o sebi i prehrani te utjecaju loših navika na prehranu i zdravlje. Četvrta skupina pitanja usmjerena je na utjecaj okoliša i pandemije bolesti COVID-19 na prehranu ispitanika. Pitanja su bila otvorenog i zatvorenog tipa. Kod zatvorenih pitanja ispitanicima je dana mogućnost da odaberu jedan od ponuđenih odgovora, a kod otvorenih pitanja mogli su samostalno formulirati odgovor. Anketa je obrađena metodama deskriptivne statistike u programu Microsoft Excel 2010 te su rezultati prikazani grafički. 


\section{Rezultati}

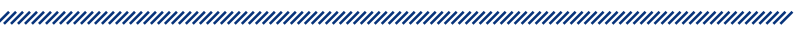

S obzirom na smjer Medicinske škole u Rijeci, najveći udio anketiranih maturanata, $27 \%$, bili su farmaceutski tehničari, slijede medicinski tehničari s udjelom od $25,7 \%$, dentalni tehničari sa $17,6 \%$, zatim tehničari nutricionisti s $14,9 \%$, sanitarni tehničari s $10,8 \%$ te fizioterapeutski tehničari s $4 \%$. Visina ispitanika (slika 1 ) kretala se od $155 \mathrm{~cm}$ do $185 \mathrm{~cm}$.

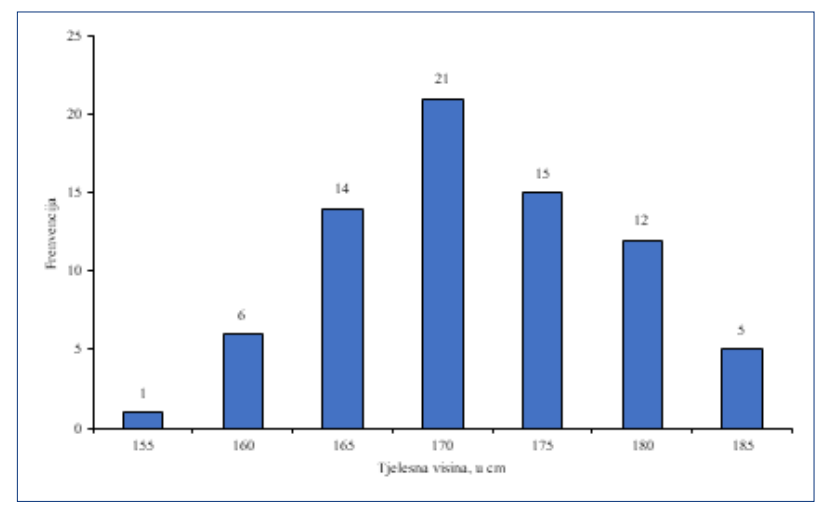

\section{Slika 1. Broj ispitanika unutar intervala tjelesne visine}

Minimalna tjelesna težina maturanata Medicinske škole u Rijeci iznosila je $45 \mathrm{~kg}$, a maksimalna $90 \mathrm{~kg}$, dok je prosječna tjelesna težina $66,1 \mathrm{~kg}$ (standardna devijacija $\pm 10,6$ ). Varijabilnost je tjelesne težine (koeficijent varijacije) maturanata Medicinske škole 16,1\%. Prosječni ITM iznosio je 23. Podaci ispitanika grupirani su u razrede i grafički prikazani na slici 2.

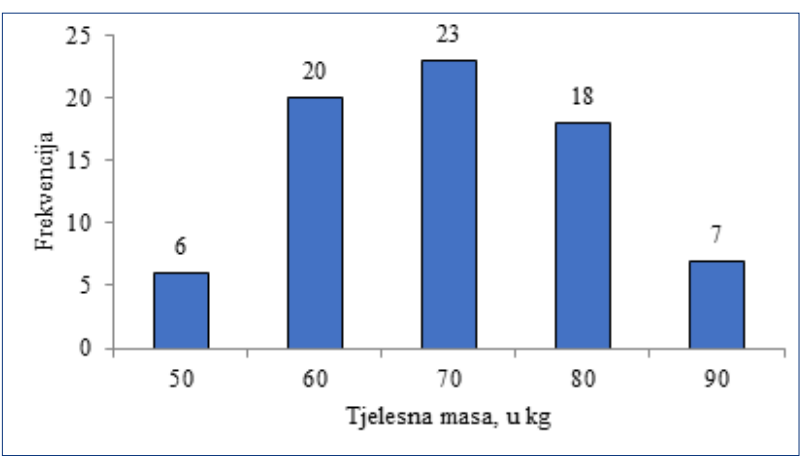

Slika 2. Broj ispitanika unutar intervala tjelesne mase

Najveći broj ispitanika, njih 54,1 \%, izjavio je kako tijekom dana imaju tri glavna obroka, a 36,5\% dva glavna obroka. Doručak konzumira većina ispitanika (82,4\%). Maturanti u manjoj mjeri kasno večeraju (44,6 \%).Većina ispitanika svakodnevno konzumira voće, njih $47,3 \%$, dvaput tjedno voće konzumira $27 \%$, jednom tjedno $23 \%$, dok 2,7 \% ispitanika uopće ne konzumira voće. Kad je riječ o povrću, 63,5 \% ispitanika svakodnevno konzumira povrće. Jednom tjedno povrće konzumira 31,1\% maturanata, dvaput tjedno $4,1 \%$, a samo jedan ispitanik nikada ne konzumira povrće. Većina ispitanika konzumira slatkiše i grickalice dvaput tjedno, njih 37,8\%. Slijede ispitanici koji ih konzumiraju svaki dan, njih $31,1 \%$, dok jednom tjedno slastice i grickalice konzumira $28,4 \%$ anketiranih. Tek dva ispitanika nikad ne jedu slatkiše i grickalice. Kad je riječ o vrsti pića koju konzumiraju, 44,6 \% ispitanika preferira vodu. Prirodne sokove pije samo $2,7 \%$ ispitanika. Više od polovice ispitanika pije jednu do dvije litre vode dnevno, njih 51,4 \%. Ribu $60 \%$ ispitanika konzumira jednom tjedno, a jednom mjesečno $25,7 \%$. Samo jednom u dva mjeseca ribu konzumira $8,1 \%$ ispitanika, dok ih 6,8\% ne jede ribu. Jednom tjedno crveno meso konzumira $75,7 \%$. Rjeđu konzumaciju crvenog mesa, jednom mjesečno, ima $13,5 \%$ ispitanika, a jednom u dva mjeseca 2,7 \%. Crveno meso ne jede 12,2 \% maturanata. Perad je u prehrani ispitanika češće zastupljena u odnosu na crveno meso. Prema anketi, 91,9 \% ispitanika konzumira perad jednom tjedno, jednom mjesečno njih 5,4 \%, a perad ne jede 2,6 \%. Gotovo su se svi ispitanici izjasnili da konzumiraju gotova jela i jela brze prehrane, kao što su pizza, hamburger i slično, njih 95,9\% (slika 3).

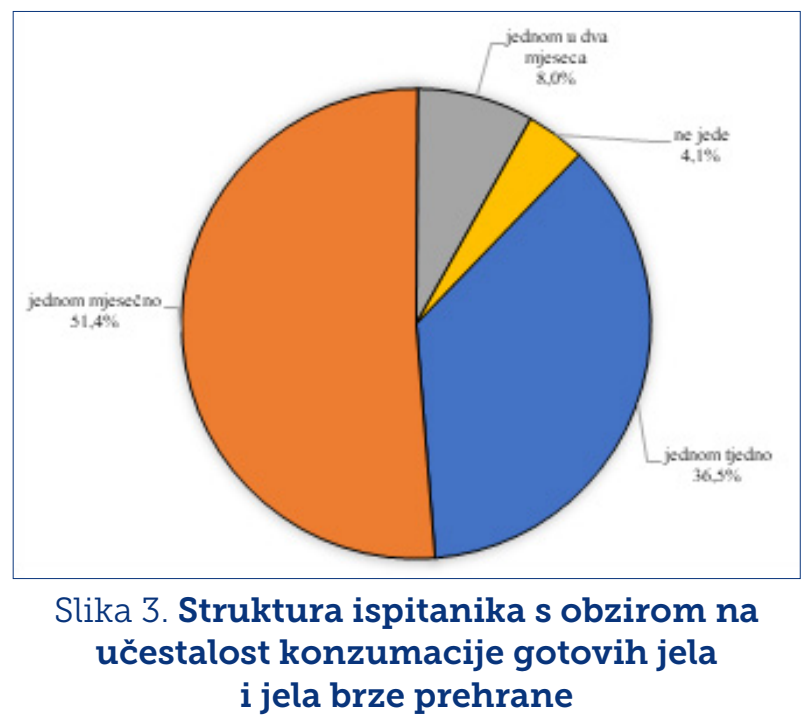

Gotova jela i jela brze prehrane jednom mjesečno konzumira 51,4\% ispitanika. Jednom tjedno jela brze prehrane konzumira $36,5 \%$ ispitanika, jednom u dva mjeseca njih $8,0 \%$. Takvu hranu ne jedu tri ispitanika. Anketom je ana- 
liziran i način pripreme hrane koji ispitanici najčešće primjenjuju. Većina ih je odgovorila kako je hrana koju jedu najčešće pripremljena kuhanjem, njih 60,8 \%, pečenjem $31,1 \%$ te prženjem $6,8 \%$. Samo jedan ispitanik najčešće jede sirovu hranu. U pripremi hrane 55,4 \% upotrebljava maslinovo ulje. Životinjsku mast u pripremi hrane upotrebljava $16,2 \%$ ispitanika, a maslac tek 2,7 \%. Treća skupina pitanja $u$ anketi odnosila se na stav maturanata o sebi i prehrani. Na pitanje „Vodite li računa o svojoj tjelesnoj masi?" većina je ispitanika dala potvrdan odgovor (60,8\%). Većina ispitanika (63,5\%) također smatra da vodi računa o zdravoj prehrani. Kako uopće ne vode računa o unosu kalorija u svojoj prehrani smatra 52,7 \% ispitanika, $36,5 \%$ ih rijetko vodi računa o unosu kalorija i samo 10,8\% smatra kako ne vodi računa o kalorijskom unosu. Na pitanje o vrsti hrane koju jedu u školi ispitanici su pekarske proizvode istaknuli kao hranu koja je najčešća, 41,9 \% konzumira razne pekarske proizvode (slika 4).

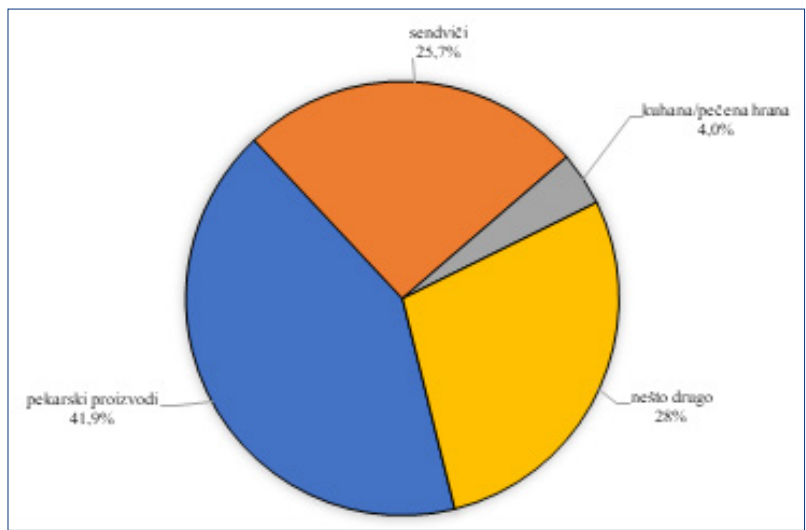

Slika 4. Struktura ispitanika s obzirom na hranu koju uobičajeno jedu u školi

Većina anketiranih (64,9\%) opisala je građu svojeg tijela normalnom i s masom u skladu sa svojim godinama i visinom. Smatra se debelima i želi smršaviti $23 \%$ ispitanika, dok je onih koji misle da su debeli i nemaju ništa protiv toga bilo $8,1 \%$. Dijetnu hranu (light proizvode i sl.) ne jede 62,2 \% maturanata. Dijetnu hranu ponekad jede $33,8 \%$ ispitanika. Na unos soli u organizam ne pazi $67,6 \%$ maturanata. Istraživanje je pokazalo manji udio ispitanika koji paze na unos šećera u organizam, njih 41,9\%. Ispitanici su mogli ocijeniti kvalitetu svoje prehrane. Pri tome im je dana mogućnost da odaberu između tri opcije: „zdrava prehrana”, „nezdrava prehrana” i „ne razmišljam o tome”. Najveći broj ispitanika, njih $56,8 \%$, procijenio je vlastitu prehranu zdravom prehranom, a 13,5\% nezdravom. Ispitanika koji ne razmišljaju o tome bilo je 29,7 \%. Većina ispitanika, njih
$81,1 \%$, ne boluje ni od kakve bolesti povezane s prehranom. Alergije na određenu hranu imaju tri ispitanika. Najveći broj maturanata kupuje voće i povrće u supermarketima, njih 58,1\%, a na tržnici $20,3 \%$. Voće i povrće samostalno uzgaja $21,6 \%$ ispitanika. Svakodnevno kavu konzumira 43,2 \% ispitanika, a ponekad 29,7\%. Kavu nikad ne konzumira $27 \%$ anketiranih. Svakodnevno ili ponekad alkoholna pića pije ih $74,3 \%$. Alkohol ne konzumira $27,7 \%$ maturanata (slika 5).

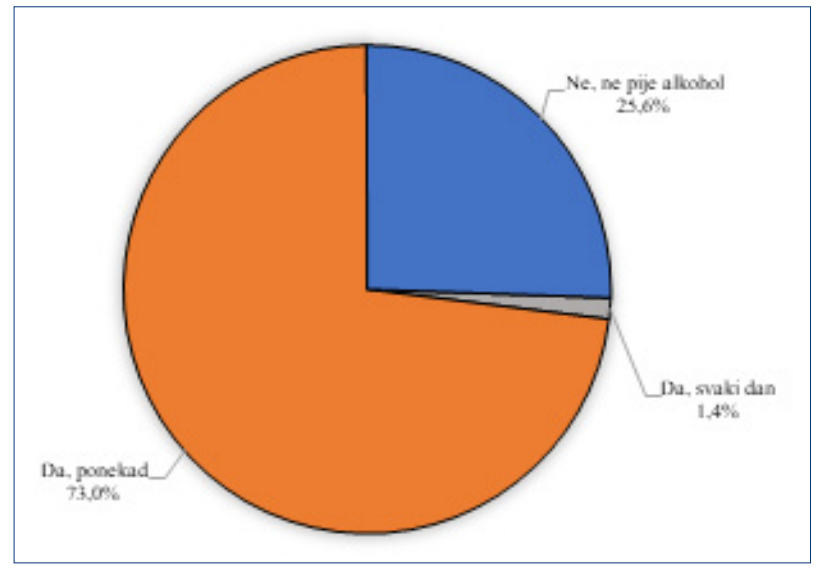

Slika 5. Struktura ispitanika s obzirom na konzumaciju alkohola

Većina ispitanika ne puši, ponekad puši 14,9 \%. Ispitanika koji puše svaki dan ima 20,2 \% (slika 6).

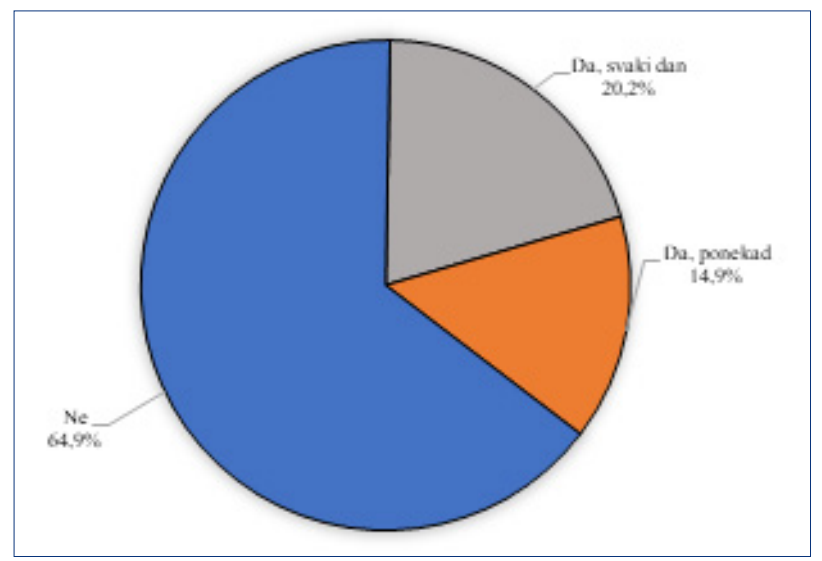

\section{Slika 6. Struktura ispitanika s obzirom na pušenje}

Svakodnevno se sportom bavi $13,5 \%$, dok za bavljenje sportom nema vremena 39,2 \% ispitanika. Većina ispitanika izjavila je kako loš san ne utječe na njihovu prehranu, njih 70,3\%. Na 18,9 \% anketiranih loš san utječe na prehranu i tada više jedu, dok na $10,8 \%$ ispitanika loš san utječe na prehranu tako što manje jedu. Na prehranu ispitanika utjecaj imaju stresne situacije. Pritom se kod 
većine ispitanika stresne situacije manifestiraju tako što jedu manje, njih 45,9 \%, a 32,4 \% ispitanika u stresnim situacijama jede više. Velika većina maturanata smatra zdravu prehranu važnom, njih 90,5\%. No svi ispitanici koji zdravu prehranu smatraju važnom ne posvećuju joj istu pažnju. Za 17,6 \% ispitanika zdrava je prehrana važna i posvećuju joj dosta pažnje, dok je za 73 ispitanika važna, ali se time previše ne opterećuju. Kako zdrava prehrana nije važna smatra $9,4 \%$ ispitanika. Da znanje iz škole utječe na njihov odabir hrane misli 59,5\% maturanata. Pandemija bolesti COVID-19 općenito je promijenila svakodnevicu ljudi, a posebice učenika u vrijeme lockdowna i održavanja nastave na daljinu. Smanjenje kretanja, stres i drugo utjecalo je na promjene povezane $s$ njihovom tjelesnom masom. Većina ispitanika, njih 37,8\%, navela je kako im se tjelesna masa povećala u odnosu na tjelesnu masu prije pandemije bolesti COVID-19. Ipak, kod 24,4\% tjelesna se masa smanjila. Većina anketiranih navela je kako COVID-19 nije utjecao na promjenu njihovih prehrambenih navika, i to $71,6 \%$. Ispitanici koji su odgovorili da je pandemija bolesti COVID-19 utjecala na promjenu njihovih prehrambenih navika naveli da su jeli više slatkiša nego inače, slastica ili grickalica, vrlo kasne večere, više brze hrane, hranu su konzumirali u bilo koje doba dana i noći (za razliku od prije pandemije, kad to nisu radili), potaknuti dosadom boravka u kući jeli su više nezdrave hrane i dr. Općenito, pandemija je imala negativne učinke na prehranu ispitanika. No pandemija bolesti COVID-19 imala je i pozitivne učinke na prehrambene navike dijela ispitanika. Tako su neki ispitanici naveli da su više jeli domaćeg voća i povrća, pekmeza i slično, konzumirali su više vode, a manje grickalica i slastica, počeli su unositi više voća i povrća kako bi ojačali imunitet, prehrana im je bila zdravija, jeli su više kuhanog povrća i općenito su se zdravije hranili, imali su više vremena koje su mogli posvetiti sebi. Navedena je skupina i smanjila tjelesnu težinu. Tijekom pandemije bolesti COVID-19 mali broj je počeo uzimati vitaminske dodatke prehrani, njih 6,8 \%, a 93, $2 \%$ nije uzimalo nikakve dodatke prehrani. Ispitanici u većem broju smatraju kako se tijekom pandemije bolesti COVID-19 promijenila njihova tjelesna aktivnost, $67,6 \%$ ih je smanjilo tjelesnu aktivnost. Većina ispitanika tijekom pandemije bolesti COVID-19 nije bila na dijeti (73\%). Ispitanici koji su tijekom pandemije bolesti COVID-19 bili na dijeti, naveli su na koji su način utjecali na smanjenje svoje tjelesne mase. Najveći broj ispitanika svoju tjelesnu masu pokušao je smanjiti povećanjem tjelesne aktivnosti ili izbjegavanjem ugljikohidrata, njih $27,3 \%$, a 9,1 \% ispitanika nastojalo je smanjiti tjelesnu masu povećanjem broja manjih obroka, preskakanjem obroka i uzimanjem preparata za mršavljenje. 


\section{PRILOG: Anketni upitnik}

Ovo je anketa kojom se žele istražiti prehrambene navike maturanata Medicinske škole u Rijeci. Anketa se sastoji od tri dijela koja obuhvaćaju općenita pitanja, svijest o prehrambenim navikama te utjecaj loših navika i pandemije bolesti COVID-19 na prehranu. Anketa je anonimna te će se vaši odgovori koristiti isključivo za istraživanje na diplomskom studiju kliničkog nutricionizma na Fakultetu zdravstvenih studija Sveučilišta u Rijeci. Unaprijed zahvaljujem na vremenu koje ste odlučili odvojiti za ispunjavanje ove ankete.

* Obvezno

1. Spol?*

Označite samo jedan oval.

o muško

o žensko

2. Smjer?*

Označite samo jedan oval.

o nutricionist tehničar

o farmaceutski tehničar

o medicinski tehničar

o dentalni tehničar

o sanitarni tehničar

o fizioterapeut

3. Dob?*

4. Koja je vaša tjelesna visina?*

5. Koja je vaša tjelesna masa?*

\section{Prehrambene navike}

6. Doručkujete li?*

Označite samo jedan oval.

o da

o ne

7. Večerate li kasno?*

Označite samo jedan oval.

o da

o ne
8. Koliko često jedete voće?*

Označite samo jedan oval.

o svaki dan

o jedanput tjedno

o dvaput tjedno

o nikad ne jedem voće

9. Koliko često jedete povrće?*

Označite samo jedan oval.

o svaki dan

o jedanput tjedno

o dvaput tjedno

o nikad ne jedem povrće

10. Koliko često jedete slatkiše i grickalice?*

Označite samo jedan oval.

o svaki dan

o jedanput tjedno

o dvaput tjedno

o nikad ne jedem slatkiše i grickalice

11. Što pijete tijekom dana?*

Označite samo jedan oval.

o samo vodu

o gazirane sokove

o prirodne sokove

o od svega pomalo

12. Koliko vode pijete?*

Označite samo jedan oval.

o manje od jedne litre

o jednu do dvije litre

o ne pijem vodu

13. Koliko često jedete ribu?*

Označite samo jedan oval.

o jednom tjedno

o jednom mjesečno

o jednom u dva mjeseca

o ne jedem ribu 
14. Koliko često jedete crveno meso?*

Označite samo jedan oval.

o jednom tjedno

o jednom mjesečno

o jednom u dva mjeseca

o ne jedem crveno meso

15. Koliko često jedete perad? ${ }^{\star}$

Označite samo jedan oval.

o jednom tjedno

o jednom mjesečno

o jednom u dva mjeseca

o ne jedem perad

16. Koliko često konzumirate gotova jela i jela brze prehrane (pizza, hamburger...)?*

Označite samo jedan oval.

o jednom tjedno

o jednom mjesečno

o jednom u dva mjeseca

o ne jedem takvu hranu

17. Kako najčešće pripremate hranu?*

Označite samo jedan oval.

o kuhanjem

o pečenjem

o prženjem

o najčešće jedem sirovu hranu

18. Koje masnoće najčešće upotrebljavate u pripremi hrane?*

Označite samo jedan oval.

o maslac

o maslinovo ulje

o rafinirana ulja

o životinjsku mast

\section{Svijest o sebi i prehrani}

19. Vodite li računa o svojoj tjelesnoj masi?*

Označite samo jedan oval.

o da

o ne

20. Vodite li računa o zdravoj prehrani?*

Označite samo jedan oval.

o da

o ne

21. Koliko dnevno imate glavnih obroka? ${ }^{\star}$

Označite samo jedan oval.

o jedan

o dva

o tri

o više od tri

22. Vodite li računa o unosu kalorija u svojoj prehrani?*

Označite samo jedan oval.

o da

o rijetko

o ne

23. Što uobičajeno jedete u školi?*

Označite samo jedan oval.

o pekarske proizvode

o sendviče

o kuhanu/pečenu hranu

o nešto drugo

24. Kako biste opisali građu svojeg tijela u odnosu na masu?*

Označite samo jedan oval.

o premršav/premršava

o normalne sam građe i mase u skladu sa svojim godinama i visinom

- debeo/debela sam i nema ništa protiv toga

o debeo/debela sam i želim smršaviti 
25. Jedete li dijetalnu hranu (light proizvode i sl.)?*

Označite samo jedan oval.
o da
o ne
o ponekad

26. Pazite li na unos soli?*

Označite samo jedan oval.
o da

o ne

27. Pazite li na unos šećera?*

Označite samo jedan oval.
o da
o ne

28. Prema vlastitoj procijeni, kakva je vaša sveukupna prehrana?*

Označite samo jedan oval.
o zdrava
o nezdrava
o ne razmišljam o tome

29. Bolujete li od kakve bolesti povezane s prehranom?*

Označite samo jedan oval.
o da, imam alergije na određenu hranu
o da, intolerantan/intolerantna sam na odre- đenu hranu
o ne

30. Gdje najčešće kupujete voće i povrće?*

Označite samo jedan oval.
o na tržnici
o u supermarketima
o uzgajam svoje voće i povrće

31. Pijete li kavu?*

Označite samo jedan oval.

o da, svaki dan

o da, ponekad

o ne
32. Pijete li alkohol?*

Označite samo jedan oval.

o da, svaki dan

o da, ponekad

o ne

33. Pušite li?*

Označite samo jedan oval.

o da, svaki dan

o da, ponekad

o ne

34. Bavite li se sportom?*

Označite samo jedan oval.

o svaki dan

o ponekad

o nemam vremena za to

35. Utječe li loš san na vašu prehranu?*

Označite samo jedan oval.

o ne utječe

o utječe, tada jedem više

o utječe, tada jedem manje

36. Koliko jedete u stresnim situacijama?*

Označite samo jedan oval.

o jedem više

o jedem manje

o stres ne utječe na moju prehranu

37. Koliko vam je važna zdrava prehrana?*

Označite samo jedan oval.

o važna mi je, posvećujem joj dosta pažnje

o važna mi je, ali se ne opterećujem previše

o nije mi važna

38. Utječe li vaše znanje iz srednje škole na odabir hrane?*

Označite samo jedan oval.

o da

o ne 
39. Je li vam se promijenila tjelesna masa u odnosu na tjelesnu masu prije pandemije bolesti COVID-19?*

Označite samo jedan oval.

o nije se promijenila

o da, tjelesna masa je veća

o da, tjelesna masa je niža

40. Je li COVID-19 utjecao na promjenu prehrambenih navika?*

Označite samo jedan oval.

o da

o ne

41. Ako je odgovor na prethodno pitanje „da”, molim vas da navedete na koji način.*

42. Jeste li u pandemiji bolesti COVID-19 počeli uzimati neke dodatke prehrani?*

Označite samo jedan oval.

o da

o ne

43. Ako je odgovor na prethodno pitanje „da”, molim vas da navedete koje dodatke prehrani.*

44. Je li se vaša tjelesna aktivnost promijenila tijekom pandemije?*

Označite samo jedan oval.

o da

o ne

45. Jeste li tijekom pandemije bolesti COVID-19 bili na dijeti?*

Označite samo jedan oval.

o da

o ne
45. Ako je odgovor na prethodno pitanje „da”, kako ste utjecali na tjelesnu masu?*

Označite samo jedan oval.

o preskakanjem obroka

o povećanjem broja manjih obroka

o izbjegavanjem ugljikohidrata

o izbjegavanjem mesa

o povećanjem tjelesne aktivnosti

o uzimanjem preparata za mršavljenje

o postom

o ostalo:

\section{Rasprava}

Suvremeni način života, posebice sjedilački način života, znatno utječe na zdravstveno stanje populacije. Fizički rad i tjelesna aktivnost zamijenjeni sjedilačkim načinom rada i života općenito, uz dostupnu hranu koja svojim pakiranjem i marketinškim akcijama privlači na povećanu konzumaciju te koja je bogata masnoćama i šećerom ugodna nepcu, uvelike su promijenili prehranu stanovništva. Tome treba dodati ubrzani način života. Tehnološki razvoj bilježi uzlaznu putanju, dok promjene aktivnosti djece i mladih u slobodno vrijeme sve više idu u smjeru smanjenja tjelesne aktivnosti.5-7 Uz sve veću mjeru izostanka slobodne igre zamijenjene obveznim aktivnostima, vrlo malo vremena ostaje za prehranu za stolom, a više za prehranu „u hodu” i slično. Nove generacije očekuju da im hrana bude brzo dostupna i ukusna te zanemaruju prehrambeni potencijal i važnost hrane. Sve to utječe na znatne promjene u prehrambenim navikama populacije, posebice mladih. Unatoč tome, provedeno istraživanje ipak daje donekle zadovoljavajuću sliku prehrambenih navika i stavova o prehrani maturanata Medicinske škole u Rijeci. Prema podacima dobivenima istraživanjem vidi se da je prosječni indeks tjelesne mase ispitanika 23 pa se može zaključiti kako maturanti Medicinske škole u Rijeci u prosjeku imaju normalnu tjelesnu težinu, jer ITM jednak ili veći od 25 označava prekomjernu tjelesnu masu. Stu- 
dije pokazuju da je vrijeme uzimanja hrane važno za pretilost i metabolizam te otkrivaju povezanost između vremena obroka, debljanja, hiperglikemije i dijabetesa s prednostima koje proizlaze iz ranog unosa hrane tijekom dana u širokom rasponu.8 Preskakanje doručka u izravnoj je povezanosti s rastom ITM-a.9 lako je doručak vrlo važan obrok u danu, jer organizmu osigurava dovoljno energije za normalno funkcioniranje tijekom dana, često se preskače ili se uzimaju namirnice koje dugotrajno ne zadovoljavaju potrebe organizma. Istraživanje koje su Cooper i suradnici proveli u Velikoj Britaniji pokazalo je da svega $55 \%$ djece u dobi od osam do deset godina svakodnevno konzumira doručak, dok je istraživanje Vareeckena pokazalo da je preskakanje doručka izraženije kod starijih adolescenata u odnosu na mlađe.9, 10 Doručku kao izrazito važnom obroku u danu većina naših maturanata posvećuje pažnju. Na to ukazuje udio maturanata koji svakodnevno doručkuje, njih $82,4 \%$. Takav odnos prema doručku upućuje na brigu maturanata o vlastitom zdravlju. No u usporedbi s istraživanjem koje su Tomić i Mesić proveli 2012., koje je pokazalo da čak $93 \%$ ispitanih studenata doručkuje, dok ih samo sedam posto nema naviku doručkovati, riječki maturanti imaju nešto nižu stopu doručkovanja.10 Pravilna prehrana podrazumijeva najmanje tri glavna obroka, a poželjno in je imati ukupno pet, računajući međuobroke. Preskakanje obroka u korelaciji je s pretilošću,9-11 a i u našem istraživanju $46 \%$ maturanta nema tri glavna obroka. Više od $36 \%$ maturanata ima samo dva obroka, a četiri posto samo jedan obrok. Više od tri obroka dnevno konzumira nešto manje od $6 \%$ maturanata. S obzirom na to da su redovitost obroka tijekom dana te odgovarajući unos hrane koja pospješuje metaboličke funkcije iznimno važni za obavljanje svakodnevnih zadataka, ispitanici bi imali koristi od promjene svojih prehrambenih navika uočenih u ovom dijelu istraživanja. Istraživanje Gu i suradnika usmjereno na metaboličke učinke kasne večere (večere pojedene u 22 sata u odnosu na 18 sati) pokazalo je veće razine šećera u krvi i nižu razinu sagorijevanja unesenih masnoća s kasnijom večerom, čak i ako je unesen isti obrok u dva različita termina.12 Prehrambene navike maturanata Medicinske škole u Rijeci ukazuju na visoku razinu zastupljenosti kasne večere, odnosno čak 44,6 \% kasno večera. Brojne studije pokazuju da je, uz preskakanje doručka, i unos kasne večere u korelaciju s pretilošću.9, 11, 12 Istraživanje koje su proveli Taveras i suradnici pokazalo je da je kasna večera usko povezana s prekomjernom težinom.13 Stoga bi bilo uputno promijeniti prehrambene navike maturanata što se tiče kasne večere. Neredoviti obroci uz unos hrane kasno ti- jekom dana nikako nisu preporučljive prehrambene navike koje omogućavaju ravnomjeran unos nutrijenata tijekom dana. S druge strane, preporučljivo je konzumiranje voća i povrća barem pet puta tijekom dana, i to dva puta voće i tri puta povrće.14 $\mathrm{U}$ ovom radu svakodnevno $47,3 \%$ maturanta konzumira voće, a $63,4 \%$ povrće. Voće uopće ne konzumira 2,7 \% ispitanika, a povrće $1,4 \%$. Iz toga se može zaključiti da njihov međuobrok nisu ni voće ni povrće, koje u međuobrocima može dati organizmu odgovarajuću razinu energije, potaknuti metabolizam i smanjiti rizik od prejedanja uslijed preskakanja međuobroka. Tijekom dana omogućavaju adekvatnu razinu energije između glavnih obroka te imaju indirektan utjecaj na stanje uhranjenosti. Međuobroke nije dobro izbjegavati, jer se snižavanjem šećera u krvi javlja stanje gladi i iscrpljenosti, što često može dovesti do prejedanja. Urednim konzumiranjem međuobroka povećava se razina energije, potiče se rad metabolizma te sprječavaju napadaji gladi. Kao što je organizmu za pravilno funkcioniranje svakodnevno potrebna hrana, tako mu je potrebna i dostatna tekućina. Svakodnevnim unosom tekućine u organizam nadoknađuje se sva ona tekućina koja se različitim fiziološkim procesima izlučuje iz organizma. Potrebe za unosom tekućine u organizam mogu se zadovoljiti vodom, cijeđenim prirodnim sokovima od voća i povrća, čajevima bez šećera, mlijekom i dr. lako nema nikakav nutritivni doprinos voda se smatra najidealnijom tekućinom za konzumiranje, dok, primjerice, prirodni sokovi od voća i povrća i čajevi imaju različite nutritivne vrijednosti te se preporučuju u umjerenim količinama. No u organizam se unose i druge tekućine, poput gaziranih pića, zašećerih sokova s niskim udjelom voća i povrća, zašećereni čajevi i drugo, koje često imaju vrlo niske ili nikakav nutritivne vrijednosti, a sadrže vrlo mnogo šećera. U provedenom istraživanju maturanti za piće najčešće uzimaju vodu, dok prirodne sokove kao piće uzima samo 2,7 \% ispitanika. Više od $80 \%$ maturanata unosi zadovoljavajuću količinu vode u organizam, odnosno količinu koja je u granicama preporuke. Unos tekućine u organizam ovisi o tjelesnoj masi. Preporuka je da se na svaki kilogram tjelesne mase unese $0,3 \mathrm{dl}$ tekućine. Od drugih napitaka posebnu pažnju treba posvetiti razumnom unošenju kave i alkohola. Kava sadrži stimulanse poput kofeina, teobromina i teofilina koji mogu imati negativne učinke na spavanje pa se preporučuje njezino umjereno konzumiranje. Alkohol, kao i kava, može imati negativne implikacije na zdravlje pa se kod njegove konzumacije preporučuje umjerenost. Rezultati istraživanja pokazali su da alkohol vrlo zastupljen među maturantima, konzumira ga gotovo $75 \%$ maturanata, bilo 
povremeno bilo svakodnevno. Poznato je da hrvatski učenici prednjače po negativnim trendovima pušenja, konzumacije alkoholnih pića i psihoaktivnih tvari u odnosu na svoje europske vršnjake, što pokazuje i Europsko istraživanje o pušenju, pijenju alkohola, uzimanju droga i drugim oblicima ovisnosti među učenicima (ESPAD) iz 2019.,15 stoga je važan odgoj i obrazovanje za zdravlje u našim školama. Riba i meso namirnice su koje sadrže kompletne proteine te su nutritivno vrlo vrijedne. Riba osigurava sve potrebne esencijalne aminokiseline, a unos ,jedne porcije ribe od 150 grama zadovoljava 50 do $60 \%$ dnevnih potreba za proteinima zdrave odrasle osobe".14 No riba zadovoljava i druge potrebe organizma, kao što je potreba za vitaminima $\mathrm{A} i$ $D$ te mineralima, posebice jodom, željezom, cinkom, selenom i dr. Razne studije ukazale su da prehrana bogata ribom pozitivno utječe na zdravlje kardiovaskularnog sustava.14 Stoga je zabrinjavajuća niska razina učestalosti konzumiranja ribe kod maturanata. Oko $60 \%$ maturanata konzumira ribu jednom tjedno, a 25,7 \% samo jednom mjesečno, dok ih $8,1 \%$ konzumira ribu jednom u dva mjeseca, a 6,8 \% nikada ne jede ribu. Cijena kao razlog ne bi smjela biti u prvom planu jer dostupnost plave ribe nije nešto što si financijski ne može priuštiti prosječna obitelj. Meso je važno u prehrani zbog sadržaja visokovrijednih proteina u kojima su sadržane sve esencijalne aminokiseline. Izvor je vitamina B12 i željeza. No zbog relativno visokog sadržaja zasićenih masnih kiselina preporučuje se ograničen unos mesa te se prednost daje krtom mesu, mesu peradi te mesu divljači.14 Crveno meso i perad su dovoljno zastupljeni u prehrani maturanata, ali zabrinjava odnos prema dodavanju soli. Sol je nužna i veoma važna za zdravlje organizma, ali u umjerenim količinama. Prekomjerna konzumacija može dovesti do niza negativnih učinaka na zdravlje, povezanih s visokim tlakom, bubrežnim kamencima, osteoporozom, bronhijalnom astmom i dr. Prema preporukama Svjetske zdravstvene organizacije (engl. World Health Organization - WHO), odrasle osobe trebale bi konzumirati manje od pet grama soli dnevno, no prosječan je unos 9 do $12 \mathrm{~g}$ na dan.16 Većina ispitanih maturanata ne pazi na unos soli ni šećera u hrani, što bi svakako bilo korisno promijeniti. Unos šećera u organizam trebao bi biti ograničen kao i unos soli. Dnevna količina unosa šećera trebala bi biti manja od $10 \%$ ukupnoga dnevnog energetskog unosa.16, 17 Primjerice, ako je osobi dnevno potrebno $1800 \mathrm{kcal}$, onda bi joj iz šećera trebalo pritjecati do $180 \mathrm{kcal}$. Anketna pitanja kojima se željelo dobiti saznanja o svijesti ispitanika o sebi i prehrani pokazala su da gotovo $40 \%$ ispitanika ne vodi računa o svojoj tjelesnoj masi, a u nešto manjem udjelu (36,5\%) ispitanici su izjavili da ne vode računa ni o zdravoj prehrani. Tome u prilog idu i podaci o udjelu ispitanika koji ne vode računa o unosu kalorija u svojoj prehrani (52,7 \%) ili koji to čine vrlo rijetko (36,5 \%). Razvijanjem svijesti o pravilnoj prehrani djeluje se u smjeru zdravog načina života i smanjenja tjelesne težine na razinu koja zadovoljava percepciju osobe o vlastitom izgledu i zdravlje organizma. Pozitivno je što u našem slučaju većina ispitanika nikada ne puši (64,9\%), s obzirom na ranije spomenute poražavajuće ukupne trendove prema istraživanjima ESPAD, ali ne možemo biti zadovoljni brojem pušača u ovom uzrastu. Znanstvene studije ukazuju na štetnost pušenja posebice u doba adolescencije, uzročnu povezanost pušenja i raka bronha i pluća, kronične opstruktivne plućne bolesti i dr. Bavljenje sportom, još je jedna od pozitivnih obilježja maturanata Medicinske škole u Rijeci. Njih 60,8 \% bavi se sportom, što je više od općeg hrvatskog prosjeka među mladima i odraslima. No ipak je i dalje prisutan visok udio onih koji navode nedostatak vremena za bavljenje sportom, a što ne bi trebalo biti razlog, jer su sa sportom povezani veliki pozitivni učinci na zdravlje. Istraživanja pokazuju kako je stres često povezan s unosom prekomjerne hrane i razvojem pretilosti.17 Rezultati ankete pokazali su i utjecaj okoline i pandemije bolesti COVID-19 na prehranu maturanta Medicinske škole u Rijeci, ali i njihov životni stil općenito. Promjene u načinu života adolescenata, manifestirane kroz održavanje nastave na daljinu, smanjene tjelesne aktivnosti i pojačani stres, glavne su odrednice promjena prehrambenih i životnih navika. Vitaminima i mineralima iz prehrane može se utjecati na jačanje imunosnog sustava, što je iznimno važno u vrijeme pandemije bolesti COVID-19.18 Tijekom pandemije bolesti COVID-19 povećan je interes za dodacima u prehrani u cilju prevencije i liječenja infekcije virusom SARS-CoV-2 i u ovoj grupi. Tome u prilog ide i činjenica da su neki ispitanici (6,8 \%) počeli uzimati dodatke prehrani u vrijeme pandemije bolesti COVID-19. Dodaci koje su uzimali odnosili su se na: vitamine B kompleksa, C i D, omega 3 masne kiseline te proteine kod ispitanika koji odlazi u teretanu. $\mathrm{U}$ dosadašnjim istraživanjima u Republici Hrvatskoj proučavale su se prehrambene navike, ali i znanje o prehrani učenika srednjih zdravstvenih škola, kao i studenata zdravstvenih smjerova. Istražujući prehrambene navike u Zdravstvenoj školi u Splitu zaključeno je da učenici imaju raznovrsnu prehranu, ali unos voća i povrća trebalo bi povećati, dok bi unos slatkiša trebalo smanjiti. Primijećeno je također da se tek polovica učenika bavi nekom sportskom aktivnošću. 19 U Zdravstvenoj i veterinarskoj školi u Vinkovcima došlo se do saznanja da su 
prehrambene navike učenika iznimno loše. Svega nekolicina učenika u svoju je prehranu uključila voće, povrće, i ribu, dok je dnevni unos slatkiša i grickalica dosta visok, a zabrinjavajući je podatak da konzumiraju i dosta alkoholnih pića. Nadalje, utvrđene su izvjesne razlike u prehrambenim navikama s obzirom na dob. Učenici viših razreda unose zadovoljavajuću razinu povrća, ribe i jaja, dok učenici nižih razreda unose više mliječnih proizvoda, kruha, žitarica i gaziranih pića. $20 \mathrm{U}$ istraživanju provedenom među studentima Zdravstvenog veleučilišta u Zagrebu zaključeno je da studenti muškog spola imaju viši ITM u odnosu na studentice. Općenito, studenti oba spola ne hrane se u skladu s preporukama pravilne prehrane u smislu odabira namirnica te konzumacije preporučenog broja dnevnih obroka, a najviše su skloni preskakanju doručka.21 Istraživanju iz travnja 2017. na maturantima Medicinske škole u Rijeci analizirano je postoji li statistički značajna razlika u utjecaju školske edukacije o pravilnoj prehrani na nutritivni status i prehrambene navike dviju ispitivanih skupina koje su činili učenici tehničari nutricionisti i dentalni tehničari. Zaključeno je da ne postoji statistički značajna razlika. Jedina je uočena razlika između ova dva razreda maturanata u kalorijskom unosu u smislu da će razred tehničara nutricionista paziti na sveukupni dnevni energetski unos, dok razred dentalnih tehničara to neće činiti.22 Sumirajući raspravu mora se naglasiti da u cjelini postoji mnogo prostora za usvajanje zdravijih stilova života, prije svega pravilne prehrane i redovite tjelesne aktivnosti maturanata, jer će to predstavljati sigurnu dobrobit za više zdravlja, duži život i veću kvalitetu zdravlja i života u odrasloj dobi.

\section{Zaključak}

Prehrana ima snažan učinak na zdravlje organizma. Pravilnom prehranom, koja podrazumijeva dobro izbalansiran unos zdravih namirnica, može se unaprijediti zdravstveno stanje organizma te smanjiti rizik oboljenja od pojedinih bolesti. Pravilna prehrana podrazumijeva konzumiranje svježeg voća i povrća oslobođenog od raznih štetnih utjecaja (zagađenja, pesticida i sl.), ribe, mesa u odgovarajućim količinama, uz ograničenje količine šećera, soli i masti. Pravilnoj prehrani treba svakako dodati i odgovarajuću tjelesnu aktivnost te dovoljno sna i izbjegavanje stresnih situacija kako bi se pozitivno djelovalo na zdravlje organizma. Rezultati istraživanja ukazali su na pozitivne trendove prehrambenih navika maturanata Medicinske škole u Rijeci te prihvaćanja pravilne prehrane kao zdrave navike srednjoškolaca. Ipak, primjetno je također da su nužna daljnja djelovanja u smislu obrazovanja i provođenja edukativnih programa koji bi povećali svijest o važnosti pravilne prehrane i brigu srednjoškolaca o vlastitom zdravlju. ${ }^{23}$ Istraživanje je pokazalo da su prehrambene navike maturanata u većini slučajeva zadovoljavajuće. Pažnju je potrebno dodatno usmjeriti na veći unos voća, povrća i ribe te promjene prehrambenih navika tijekom boravka u školi, preskakanje obroka i kasne večere. Posebnu pažnju treba usmjeriti i na edukaciju srednjoškolaca o štetnosti alkoholnih pića i duhanskih proizvoda. ${ }^{23}$ Dodatnim ispitivanjem znanja kod maturanata mogao bi se dobiti bolji uvid u prehrambene navike u smislu razumijevanja prehrane, odnosno razloge zbog kojih ne prihvaćaju pojedine opće preporuke pravilne prehrane. Osim toga, istraživanje provedeno na većem uzorku dalo bi vjerodostojnije podatke, a uključenje medicinskih škola iz drugih regija moglo bi dati i podatke o prehrambenim navikama maturanata ovisno o utjecaju regionalne različitosti u prehrambenim navikama. Provedeno istraživanje dobra je podloga za poboljšanje prehrambenih navika mladih, njihovo dodatno educiranje povezano sa samim prehrambenim navikama, ali i podloga za istraživanja koja bi uključila druge čimbenike koji utječu na zdravlje organizma, primjerice istraživanja povezanosti prehrambenih navika i tjelesne aktivnosti te pronalaženje i pokretanje javnozdravstvenih preventivnih programa koji će spriječiti daljnji porast tjelesne težine i pretilost u odrasloj dobi, koja dokazano smanjuje kvalitetu zdravlja i trajanje zdravih godina života.

\section{Referencije}

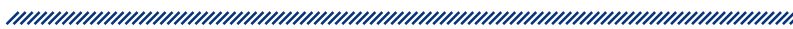

1. Musić-Milanović S. Prehrana djece, Ukusno i zdravo [internet]. Dostupno na: https://www.zzjzpgz.hr/nzl/38/dodatak.htm (pristupljeno 1. kolovoza 2021.).

2. Šimundić B. Zdrava prehrana - značajna resursna osnovica zdravstvenog turizma [internet]. Tourism and hospitality management; 1996; 2 (2): 357-368. Dostupno na: https://hrcak.srce.hr/182456 (pristupljeno 1. kolovoza 2021.).

3. Centre for Health Protection. The Food Pyramid - A Guide 
to a Balanced Diet. Dostupno na: https://www.chp.gov. hk/en/static/90017.html (pristupljeno 2. kolovoza 2021.).

4. Paklarčić M, Kukuć E, Karakaš S, Osmanil, Kerić E. Prehrana i razlike u prehrani školske djece u urbanoj i ruralnoj sredini na području općine Travnik [internet]. Tuzla: Hrana u zdravlju i bolesti; 2013; 2 (2): 50-57. Dostupno na: https://hrcak.srce.hr/index.php?show=clanak\&id_clanak_jezik=172942 (pristupljeno 4. kolovoza 2021.).

5. Čulina T, Anđelić Breš S. Povezanost samopoštovanja s prehrambenim navikama, uhranjenošću, sportom, spolom i dobi u riječkih adolescenata [internet]. Medica Jadertina 2014; 44 (1-2): 5-12. Dostupno na: https:// hrcak.srce.hr/index.php?show=clanak\&id_clanak_jezik=180896 (pristupljeno 28. srpnja 2021.).

6. Abraham S, Noriega Brooke R, Shin JY. College students eating habits and knowledge of nutritional requirements. J Nutr Hum Health 2018; 2 (1): 13-17. https://doi. org/10.35841/nutrition-human-health.2.1.13-17

7. Bočina I. Debljina - javnozdravstveni izazov današnjice [internet]. Rijeka: Narodni zdravstveni list svibanj/lipanj; 2007. Dostupno na: https://www.zzjzpgz.hr/nzl/45/ nzl_5_6_2007.pdf (pristupljeno 11. kolovoza 2021.).

8. Beccuti G, Monagheddu C, Evangelista A, Ciccone G, Broglio F, Soldati L, Bo S. Timing of food intake: Sounding the alarm about metabolic impairments? A systematic review. Pharmacol Res 2017;125:132-141. https:// pubmed.ncbi.nlm.nih.gov/28928073/

9. Mirghani $\mathrm{H}$. The Effect of Breakfast Skipping and Late Night Eating on Body Mass Index and Glycemic Control Among Patients With Type 2 Diabetes Mellitus. Cureus 2021; 13 (6) :e15853. https://www.ncbi.nlm.nih.gov/ pmc/articles/PMC8299536/

10. Tomić M, Mesić Ž. Utjecaj sociodemografskih obilježja hrvatskih studenata na navike doručkovanja [internet]. Dubrovnik: Zbornik radova 48. hrvatskog i 8. međunarodnog simpozij agronoma; 2013; 13 (5): 899-906. Dostupno na: http://sa.agr.hr/pdf/2013/sa2013_p0223.pdf (pristupljeno 14. kolovoza 2021.).

11. Smešny V. Pretilost je bolest! [internet]. Narodni zdravstveni list svibanj/lipanj; 2007; 3. Dostupno na: https:// www.zzjzpgz.hr/nzl/45/nzl_5_6_2007.pdf (pristupljeno 11. kolovoza 2021.).

12. Gu Chenjuan, Brereton N, Schweitzer A, Cotter M, Duan,D et al. Metabolic Effects of Late Dinner in Healthy Volunteers - A Randomized Crossover Clinical Trial. The Journal of Clinical Endocrinology \& Metabolism 2020; 105 (8): 2789-2802. https://doi.org/10.1210/clinem/dgaa354

13. Taveras E., Rifas-Shiman SL, Berkey CS, Rockett HRH, Alison EF, Frazier AL et al. Family dinner and adolescent overweight. Obes Res 2005; 220-224. https://pubmed. ncbi.nlm.nih.gov/15919844/

14. Jirka Alebić I. Prehrambene smjernice i osobitosti osnovnih skupina namirnica [internet]. Medicus; 2008; 17 (1): 37-46. Dostupno na: https://hrcak.srce.hr/index. php?show=clanak\&id_clanak_jezik=59753 (pristupljeno 16. kolovoza 2021.).
15. Europsko istraživanje o pušenju, pijenju alkohola, uzimanju droga i drugim oblicima ovisnosti među učenicima (ESPAD) 2019 [internet]. Dostupno na: https://www. hzjz.hr/sluzba-promicanje-zdravlja/europsko-istrazivanje-o-pusenju-pijenju-alkohola-uzimanju-droga-i-drugim-oblicima-ovisnosti-medu-ucenicima-espad-2019/ (pristupljeno 14. srpnja 2021.).

16. Tomić J. Evo odgovora koliko soli i šećera trebate konzumirati! [internet]. 2016. Dostupno na: https://www. zzjzpgz.hr/nzl/45/nzl_5_6_2007.pdf (pristupljeno 13. kolovoza 2021.).

17. Maslarda D, Uršulin-Trstenjak N, Bressan L. Poremećaj u prehrani - pretilost: prehrambene navike, tjelesna aktivnosti i samoprocjena BMI u Hrvatskoj [internet]. Journal of Applied Health Sciences, 2020; 6 (1): 83-90. Dostupno na: https://hrcak.srce.hr/index.php?show=clanak\&id_ clanak_jezik=341689 (pristupljeno 10. kolovoza 2021.).

18. Rugole V, Pucarin-Cvetković J, Milošević M. Suplementi u prehrani zdravstvenih djelatnika tijekom pandemije COVID-19 [internet]. Sestrinski glasnik, 2021; 26 (2): 82-91. Dostupno na: https://doi.org/10.11608/sgnj.26.2.1 (pristupljeno 10. kolovoza 2021.).

19. Kendeš M. Prehrambene navike adolescenata na području splitsko-dalmatinske županije [Diplomski rad]. Split: Sveučilište u Splitu, Medicinski fakultet; 2021. Dostupno na: https://urn.nsk.hr/urn:nbn:hr:171:523667 (pristupljeno 23. kolovoza 2021.).

20. Brnčić B. Prehrambene navike adolescenata [diplomski rad]. Osijek: Sveučilište Josipa Jurja Strossmayera u Osijeku, Medicinski fakultet Osijek; 2017. Dostupno na: https://urn.nsk.hr/urn:nbn:hr:152:979308 (pristupljeno 23. kolovoza 2021.).

21. Peronja M. Prehrambene navike i znanje o prehrani studenata zdravstvenog usmjerenja [diplomski rad]. Rijeka: Sveučilište u Rijeci, Fakultet zdravstvenih studija u Rijeci; 2018. Dostupno na: https://urn.nsk.hr/ urn:nbn:hr:184:047074 (pristupljeno 22. rujna 2021.).

22. Velnić N. Utjecaj sustava edukacije na nutritivni status i prehrambene navike u adolescenta [diplomski rad]. Rijeka: Sveučilište u Rijeci, Fakultet zdravstvenih studija u Rijeci; 2018. Dostupno na: https://urn.nsk.hr/ urn:nbn:hr:184:574017 (pristupljeno 22. rujna 2021.).

23. Gudeljević M. Prehrambene navike maturanata Medicinske škole u Rijeci [diplomski rad]. Rijeka: Fakultet zdravstvenih studija, 2021. 


\section{HABITS AND ATTITUDES ABOUT THE NUTRITION OF MEDICAL SCHOOL GRADUATES}

1 Marija Gudeljević

2 Željko Jovanović

1 Klinički bolnički centar Rijeka

2 Sveučilište u Rijeci, Fakultet zdravstvenih studija ing time spent in school, skipping meals and having late dinners, and educating high school students about the harmfulness of alcoholic beverages and tobacco products. Further education and educational programs on proper nutrition and its effects on health have a preventive effect on the health of thes population as a whole.

\section{Abstract}

Eating habits have an important impact on the health of the body. Proper nutrition, which includes a balanced quantity and quality of food intake, consumption of fresh fruits and vegetables free from various harmful effects (pollution, pesticides, etc.), fish, meat in appropriate quantities, limited amounts of sugar, salt and fat, etc., can improve the health of the organism and reduce the risk of certain diseases. Developing awareness of proper nutrition in adolescents is extremely important in the prevention of various diseases at a later age (cardiovascular disease, malignant diseases, etc.). The study conducted on a sample of 74 graduates of the Medical School in Rijeka showed a positive attitude of high school graduates regarding healthy eating and acceptance of proper nutrition as a way of life for high school graduates. The BMI of the respondents is 22.87 , which indicates that the graduates of the Medical School in Rijeka have a normal body weight on average. The results of the survey showed satisfactory eating habits of high school graduates. Dietary deficiencies were observed in the consumption of fruits and vegetables and fish. Attention should be paid to changes in eating habits dur-
Key words: eating habits, graduates, proper nutrition, prevention, health 